\title{
Dehydration Kinetics and Infusion Attributes of Microwave Dried Olive Leaves
}

\author{
Ömer Faruk Gamlı*, Özge Süfer, Tülin Eker \\ Food Engineering Department, Faculty of Engineering, Osmaniye Korkut Ata University, 80000 Osmaniye, Turkey.
}

\section{A R T I C LE INFO}

\section{Research Articles}

Received 27 September 2017

Accepted 17 July 2018

Keywords:

Microwave drying

Mathematical modeling

Olive leaves

Tea

Infusion

"Corresponding Author:

E-mail: omergamli@osmaniye.edu.tr

\begin{abstract}
A B S T R A C T
Olive leaves have been catching consumers' and researchers' great interest because of benefits on human health. In this study, the olive leaves were dried by microwave method at different powers $(52,90,167,290,347 \mathrm{~W}$ real effective power levels) and drying kinetics of olive leaves were examined to find the best mathematical model. Page model was the most suitable model rather than the others. Diffusion coefficients were ranged between $2.65 \times 10^{-10}$ to $6.87 \times 10^{-10} \mathrm{~m}^{2} / \mathrm{s}$ and an increment in power level promoted moisture diffusivities. Dried olive leaves were used to get leave tea and different infusion temperatures were investigated to recover the total polyphenols ( $\mathrm{mg} \mathrm{GAE} / \mathrm{kg}$ ) and radical scavenging activities (\%). Rising in infusion temperature, especially at $100^{\circ} \mathrm{C}$ enhanced the extraction levels of polyphenols from leave tea. Olive leaves dried at $167 \mathrm{~W}$ had higher phenolic contents (2282.9 mg GAE/kg) among all samples.
\end{abstract}

Türk Tarım - Gida Bilim ve Teknoloji Dergisi, 6(8): 963-970, 2018

\section{Mikrodalga ile Kurutulmuş Zeytin Yapraklarının Kurutma Kinetikleri ve Demleme Özellikleri}

M A K A L E B İ L G İ S İ

\section{Araştırma Makalesi}

Geliş 27 Eylül 2017

Kabul 17 Temmuz 2018

Anahtar Kelimeler:

Mikrodalga kurutma

Matematik modelleme

Zeytin yaprağ 1

Çay

Demleme

*Sorumlu Yazar:

E-mail: omergamli@osmaniye.edu.tr

\section{Ö Z}

Zeytin yaprakları, sağlık üzerindeki olumlu etkilerinden dolayı araştırmacıların ve tüketicilerin ilgisini çekmektedir. Bu çalışmada, zeytin yaprakları mikrodalga uygulaması ile 52, 90, 167, 290, $347 \mathrm{~W}$ gerçek etkin güç seviyelerinde kurutulmuş ve kurutma kinetikleri, kurutma davranışını en iyi betimleyen matematik modelin belirlenebilmesi maksadıyla incelenmiştir. Page model, diğerlerinin içerisinde en uygun model olarak tespit edilmiştir. Difüzyon katsayıları $2,65 \times 10^{-10}-6,87 \times 10^{-10} \mathrm{~m}^{2} / \mathrm{s}$ aralı̆̆ında hesaplanmış olup, güç düzeyindeki artışı, difüzyon katsayısında da artışa sebep olduğu görülmüştür. Kurutulmuş zeytin yaprakları çay elde etmek amacıyla kullanılmış ve farklı demleme sıcaklıklarının, çayın toplam polifenol (mg GAE/kg) ve radikal süpürme aktivitesi (\%) üzerindeki etkileri araştırılmıştır. Demleme sıcaklığındaki artışın, özellikle $100^{\circ} \mathrm{C}$ 'de polifenollerin özütlenmesini arttırdığı görülmüştür. $167 \mathrm{~W}$ 'da kurutulmuş olan zeytin yapraklarının $(2282,9 \mathrm{mg} \mathrm{GAE} / \mathrm{kg})$ diğer güçlerde kurutulanlara oranla daha fazla fenolik içeriğine sahip olduğu açığa çıkmıştır. 


\section{Introduction}

Drying of foodstuffs can be made by many methods such as convective, microwave, vacuum or freeze drying (Lewicki, 2006; Figiel, 2010). Convective drying which is widely used for the production of dehydrated fruits and vegetables requires relatively long times and high drying temperatures cause degradation of important nutritional compounds as well as color changes (Chua et al., 2001; Maskan, 2001). Microwave drying is a modern drying technique that has great efficiency of food preservation and energy is absorbed by water located in the whole volume of food materials being dried. Large amount of vapor pressure is occurred in the center of food material allowing rapid transfer of moisture to the surrounding vacuum and preventing structural collapse (Figiel, 2010). The most important factor of microwave heating is power which enhances drying and evaporation rate that is considerably higher than convective drying (Sharma and Prasad, 2004).

Olive is one of the most cultivated products annually in the world and Mediterrenean countries have the biggest share (nearly 98\%). Valuable by-products of olive are olive leaves and olive pomace. Leaves can contain small twigs and branches and total biomass of leaves in oil industry is between 3 and 5\% (Souilem et al., 2017; El and Karakaya, 2009). The major uses of leaves are in animal feed (Paiva-Martins and Pinto, 2008) and Mediterrenean folk medicine (Omar, 2010) because of containing a great quantity of polyphenols and flavonoids. The most abundant polyphenolic compounds in olive leaves are oleuropein and hydroxytyrosol. It is reported that extraction of olive leave which contains higher amount of oleuropein prevents the oxidation of lipoprotein that plays important role as a food additive (Visioli et al., 1995; Tuck and Hayball, 2002).

The nutritive value of olive leaves is quite high and it has great effects on health such as supporting immune system, protecting cardiovascular system and preventing cancers, so olive leaves can be converted into different products to get these pharmacological effects. One of the products is olive leave tea that is produced from the sundried olive leaves (at atmospheric conditions) which are milled to the small particles at a size of 2-3 mm, sieved and packaged in tea bags (2.5-3 g) (Nurs Company, Adana, Turkey).

Erbay and İçier (2009) dried olive (Memecik cv.) leaves at a temperature interval of $40-60^{\circ} \mathrm{C}$ with air velocity range of $0.5-1.5 \mathrm{~m} / \mathrm{s}$ during $240-480 \mathrm{~min}$ respectively. Chemlali, Chemchali, Zarrazi and Chetoui cultivars were also studied by Boudhrioua et al. (2009) (infrared drying) and Nourhène et al. (2008) (solar drying). Studies about microwave drying of olive leaves focused on mathematical modeling as well as its phenolics and antioxidant activity were not found in current literature.

The aims of this work were (i) to determine the effect of microwave power on the drying kinetics of olive leaves, (ii) to fit the experimental data to mathematical models available in the literature, (iii) to confirm the total phenolic contents (mg GAE/kg) and radical scavenging activity (\%) of olive leaf teas.

\section{Material and Method}

\section{Material}

Leaves of Gemlik olive cultivars that were grown at province of Osmaniye, Turkey were collected from olive planted region including 405 olive trees characterized by a typical Mediterranean climate with a long-term average annual temperature of $18.3^{\circ} \mathrm{C}$ (T.S.M.S., 2015).

\section{Method}

Power measurement of microwave dryer: Real effective power levels were determined by using International Microwave Power Institute (IMPI) 2 Liter Test according to Buffler, 1993. The dryer was operated at 5 different power stages indicated on machine (90, 180, 360,600 and $900 \mathrm{~W}$ ) with $2000 \mathrm{~g}$ of pure water placed in 2 glass beakers (1 liter). Initial temperatures of waters were measured and then the dryer was run for $122 \mathrm{~s}$. Final temperatures were recorded immediately and equation 1 was used to compute actual powers. The tests were performed in duplicate.

$$
\mathrm{P}_{\mathrm{r}}=\frac{m \times C_{p} \times\left(\Delta T_{1}+\Delta T_{2}\right)}{2 \Delta t}
$$

Where $P_{r}$ is real effective power $(\mathrm{W}), \mathrm{m}$ is mass of water $(\mathrm{kg}), \mathrm{C}_{\mathrm{p}}$ is specific heat of water at average initial temperature $\left(26^{\circ} \mathrm{C}\right), \quad\left(\mathrm{J} / \mathrm{kg}^{\circ} \mathrm{C}\right), \Delta \mathrm{T}_{1}$ and $\Delta \mathrm{T}_{2}$ are temperature gradients in two beakers $\left({ }^{\circ} \mathrm{C}\right)$ and $\Delta \mathrm{t}$ is time in seconds. The average microwave outputs were calculated as 52, 90, 167, 290 and $347 \mathrm{~W}$ instead of 90, 180, 360, 600 and $900 \mathrm{~W}$ respectively.

Drying procedure: After collecting leaves (contained $52.61 \%$ level of moisture) from tree, they were washed and waited on the bench until surface moisture evaporated spontaneously. Then, fresh olive leaves were milled with a commercial lab blender (Waring, 8009L, Germany) into 2-3 mm sieve size averagely. In order to maximize phenolic recovery and minimize the losses of nutritions, this pretreatment had been accepted as an obligatory. 15 grams of crumbled olive leaves were spreaded on an aluminum metal plate (with a thickness of $0.0025 \mathrm{~m}$ ) and then subjected to drying in a home-type microwave dryer (Bosch HMT84G, Germany), at 52, 90, 167, 290 and 347 $\mathrm{W}$ discontinuously (heating cycle was in an every $18 \mathrm{~s}$ for a time period of $10 \mathrm{~s}$ ) and the weight of samples was recorded in every ten seconds manually using a digital balance (OHAUS, Pioneer ${ }^{\mathrm{TM}}$, PA 114, USA) until the equilibrium moisture content was achieved.

Infusion: For preparation of tea, $3 \mathrm{~g}$ of olive leaves dried at 52, 90, 167, 290 and $347 \mathrm{~W}$ were put into glass container which contained $60 \mathrm{~mL}$ distilled water for infusing during 8-10 minutes at different temperatures between $30-100^{\circ} \mathrm{C}$ (Anonymous, 1983). Two replicates for each sample were performed. The analyzes were carried out in duplicate.

Mathematical modeling, moisture diffusivity and drying rate: 11 different mathematical equations were used to describe the drying kinetics of olive leaves and listed in Table 1. 
Table 111 different thin layer mathematical models

\begin{tabular}{|c|c|c|}
\hline Model name & Equation & Reference \\
\hline Newton (Lewis) & $\mathrm{MR}=\exp (-\mathrm{k} . \mathrm{t})$ & Wictor et al. 2013 \\
\hline Page & $\mathrm{MR}=\exp \left(-\mathrm{k} \cdot \mathrm{t}^{\mathrm{n}}\right)$ & Doymaz, 2007 \\
\hline Modified Page & $\mathrm{MR}=\exp (-\mathrm{k} \cdot \mathrm{t})^{\mathrm{n}}$ & Sharma et al. 2011 \\
\hline Henderson \& Pabis & $\mathrm{MR}=\mathrm{a} \cdot \exp (-\mathrm{k} . \mathrm{t})$ & Doymaz, 2007 \\
\hline Logarithmic & $\mathrm{MR}=\mathrm{a} \cdot \exp (-\mathrm{k} \cdot \mathrm{t})+\mathrm{c}$ & Toujani et al. 2013 \\
\hline Two-term & $\mathrm{MR}=\mathrm{a} \cdot \exp \left(-\mathrm{k}_{1} \cdot \mathrm{t}\right)+\mathrm{b} \cdot \exp \left(-\mathrm{k}_{2} \cdot \mathrm{t}\right)$ & Toujani et al. 2013 \\
\hline Approximation of diffusion & $M R=a \cdot \exp (-k \cdot t)+(1-a) \cdot \exp (-k \cdot a \cdot t)$ & Toujani et al. 2013 \\
\hline Wang \& Sing & $\mathrm{MR}=1+\mathrm{a} \cdot \mathrm{t}+\mathrm{b} \cdot \mathrm{t}^{2}$ & Sharma et al. 2011 \\
\hline Simplified Fick's diffusion & $\mathrm{MR}=\mathrm{a} \cdot \exp \left(\mathrm{c} .\left(\mathrm{t} / \mathrm{L}^{2}\right)\right)$ & Toujani et al. 2013 \\
\hline Midilli et al. & $\mathrm{MR}=\mathrm{a} \cdot \exp \left(-\mathrm{k} \cdot \mathrm{t}^{\mathrm{n}}\right)+\mathrm{b} \cdot \mathrm{t}$ & Midilli et al. 2002 \\
\hline Polynomial & $\mathrm{MR}=1+\mathrm{a} \cdot \mathrm{t}+\mathrm{b} \cdot \mathrm{t}^{2}+\mathrm{c} \cdot \mathrm{t}^{3}$ & Gamli, 2011 \\
\hline
\end{tabular}

Regression analysis was performed using Mathlab (R2009b) in order to select the best model. The correlation coefficient $\left(\mathrm{R}^{2}\right)$ and root of mean square of error (RMSE) were also calculated. The higher $\mathrm{R}^{2}$ and lower RMSE indicated that the model fitted better to the experimental data. Moisture distribution was considered initially uniform in the material, moisture diffusivity was homogeneous throughout the leaf powder, moisture moved from center to its the surface directly, heat losses were negligible, no chemical reactions occurred and heat transfer was only accepted in one direction. Moisture diffusivity equation is as follows:

$$
\mathrm{MR}=8 / \Pi \exp \left[\mathrm{D}_{\mathrm{eff} .} \Pi^{2} . \mathrm{t} /(\mathrm{L} / 2)^{2}\right]
$$

MR: Moisture ratio

$D_{\text {eff: }}$ Moisture diffusivity $\left(\mathrm{m}^{2} / \mathrm{s}\right)$

L: thickness of crumbled leaves on metal plate (m) $(0.0025 \mathrm{~m})$

Moisture ratio (MR) was calculated with the help of equation (3):

$\mathrm{MR}=\left(\mathrm{M}-\mathrm{M}_{\mathrm{e}}\right) /\left(\mathrm{M}_{0}-\mathrm{M}_{\mathrm{e}}\right)$

M: Moisture content at specific time (g water)

$\mathrm{M}_{0}$ : Initial moisture content ( $\mathrm{g}$ water)

$\mathrm{M}_{\mathrm{e}}$ : Moisture content at equilibrium ( $\mathrm{g}$ water)

Free moisture (FM) (g water) level and drying rate (DR) were determined by the following equations;

$$
\begin{aligned}
& \mathrm{FM}=\mathrm{M}-\mathrm{M}_{\mathrm{e}} \\
& \mathrm{DR}=\frac{\Delta M}{A \times \Delta t}
\end{aligned}
$$

$\Delta \mathrm{M}$ : Difference in moisture content at specific time ( $\mathrm{g}$ water)
A: Drying area $\left(\mathrm{m}^{2}\right)$
$\Delta \mathrm{t}$ : Difference in time (s)

Total phenolic content (TPC): Total phenolic contents (TPC) of leave tea extract were determined colorimetrically using the Folin-Ciocalteu reagent. $0.5 \mathrm{~mL}$ aliquot of the sample was transferred to a glass tube. 0.5 $\mathrm{mL}$ of $\mathrm{FC}$ reagent was added after 5 min followed by 2 $\mathrm{mL}$ of $\mathrm{Na}_{2} \mathrm{CO}_{3}$ solution $(200 \mathrm{mg} / \mathrm{mL})$. The sample was mixed by a vortex (Stuart, SA7, UK) and the reaction proceeded for $15 \mathrm{~min}$. at ambient temperature. Afterwards, $10 \mathrm{~mL}$ of distilled water was added and the formed precipitate was removed by centrifugation (Hettich, Universal 320R, Germany) for $5 \mathrm{~min}$ at $4000 \mathrm{~g}$. Finally, absorbance was measured at $725 \mathrm{~nm}$ using a spectrophotometer (Shimadzu UV-1800, Kyoto, Japan) and results were expressed as $\mathrm{mg}$ gallic acid equivalent (GAE)/kg dry matter (DM) (Huang et al. 2005).

Radical scavenging activity (RSA):The antioxidant activities of phenolic extracts obtained from olive leave tea were determined by the DPPH method. $0.1 \mathrm{~mL}$ of the extracted solution was added to $2.9 \mathrm{~mL}$ DPPH solution and it was kept in dark for about $30 \mathrm{~min}$. The absorbance value was measured at $515 \mathrm{~nm}$ by spectrophotometer (Shimadzu UV 1800, Kyoto, Japan). The radical scavenging activity of leave samples was expressed as the percentage inhibition of the DPPH radical within the following equation (Huang et al., 2005; Ferreira et al., 2007):

$$
\text { RSA, } \%=\left[\left(\mathrm{A}_{\text {control }}-\mathrm{A}_{\text {sample }}\right) / \mathrm{A}_{\text {control }}\right] \times 100
$$

Where $\mathrm{A}_{\text {control }}$ is the absorbance of control, $\mathrm{A}_{\text {sample }}$ is the absorbance of sample at $515 \mathrm{~nm}$.

\section{Statistical Analysis}

The statistical differences between the results of infusion, total phenolic content and radical scavenging activity were analyzed by Duncan test using an analysis of variance (ANOVA) procedure with SPSS software version 18.0 at a significance level of 0.05 .

\section{Results and Discussion}

\section{Drying Kinetics}

The initial moisture content of olive leaves was 1.109 $\mathrm{kg}$ water $/ \mathrm{kg}$ dry matter. Final moisture contents of microwave dried olive leaves were changed from $0.38 \%$ to $0.12 \%$ at $52-347 \mathrm{~W}$ respectively. As expected, microwave heating power positively affected the drying characteristics of olive leaves. Figure 1a depicted the profile of moisture ratio (MR) during drying process and Figure $1 \mathrm{~b}$ illustrated the drying rates versus free moisture levels of olive leaves under different microwave powers $(52-347 \mathrm{~W})$. Drying results showed that an increase in drying power of microwave led to a decrease in the time required to achieve definite moisture content. A similar behavior was observed in our another study which was 
conducted in a laboratory type dryer with olive leaves at 50,60 and $70^{\circ} \mathrm{C}$. When drying temperature was increased, drying rate also enhanced, hence drying time reduced (Gamli et al., 2016).

As shown in Figure 1b, there was no constant rate period in the range of microwave powers studied, all drying process occurred in falling rate and drying rate decreased continuously with drying time as moisture content fell. The increased molecular vibration due to absorption of microwaves generated heat simultaneously at the surface and the inner layers of samples at which the rate of water removal increased (Puente-Diaz et al., 2013). Moisture was supplied from the interior of the solids towards to the surface in order to maintain the rate of evaporation due to the higher moisture content under the applied microwave heating power which positively affected the rate of water removal from olive leaves. In microwave drying process, olive leaves were exposed to a microwave heater which impinged on the leaf surface and penetrated into the leaves so, rapid drying took place.

\section{Modeling of Drying Curves and Moisture Diffusivity}

11 thin layer mathematical models were applied to fit the drying data of olive leaves and Page model had the highest regression coefficient $\left(\mathrm{R}^{2}\right)$ and the lowest root of mean square of errors (RMSE) at all microwave power levels. Table 2 shows the statistical results of all models also including model constants and regression coefficients. Nourhène et al. (2008) was also expressed the Page model was the superior than Newton and Henderson and Pabis models for dehydration of four varieties of olive leaves using an indirect forced convective solar dryer consisting of a solar collector, an auxiliary heater, a circulation fan and a drying cabinet. On the contrary, Erbay and İçier (2010) stated that Henderson and Pabis model was the best among 11 mathematical expressions for describing air (tray) drying phenomena of Memecik cv. olive leaves at temperature range of 50 $70^{\circ} \mathrm{C}$ and air flow rate of $0.5-1.5 \mathrm{~m} / \mathrm{s}$. Differences may be arised from material, drying technique and the number of tested models.

According to the fitting results of Page model the drying rate constant $(\mathrm{k})$ which characterized the rate of moisture removal from the materials was found in the range of 0.110 to $0.582 \mathrm{1} / \mathrm{min}$. The drying rate constant showed higher values at higher microwave powers which enhanced the drying rate by generating more heat energy inside the materials (Gaware et al., 2010). The $\mathrm{k}$ values increased with increasing drying temperature in drying of flax fiber $\left(30-70^{\circ} \mathrm{C}\right)$ (Ghazanfari et al., 2006), pine residue $\left(40-80^{\circ} \mathrm{C}\right)$ (Phanphanich and Mani, 2009) and bamboo slices $\left(45-65^{\circ} \mathrm{C}\right.$ ) (Kumar et al., 2013), thus microwave drying results confirmed increasing microwave power also increased the rate constant, $\mathrm{k}$. The power term, $\mathrm{n}$ was found in the range of 0.663 to 1.868 in Page model (Table 2) and it did not show any systematic pattern. The $\mathrm{n}$ values for $90-347 \mathrm{~W}$ of microwave were more than 1.0 and $\mathrm{n}$ value was lower than 1.0 for $52 \mathrm{~W}$ of microwave heating power.

The estimated moisture diffusivities of olive leaves increased with microwave power, the values varied from $2.650 \times 10^{-10}$ to $1.320 \times 10^{-9}\left(\mathrm{~m}^{2} / \mathrm{s}\right)$ in the range of 52 to 347 $\mathrm{W}$ and regression coefficients, $\mathrm{R}^{2}$ were changed from 0.989 to 0.999 . These values were compatible with those reported for cassava cultivars $\left(0.280 \times 10^{-9}-0,300 \times 10^{-9}\right.$ $\mathrm{m}^{2} / \mathrm{s}$ at $70^{\circ} \mathrm{C}$ and $95 \mathrm{~W}$ ) (Goncalves et al., 2017), for bananas $\left(0.489 \times 10^{-9}-0.109 \times 10^{-8} \mathrm{~m}^{2} / \mathrm{s}\right.$ at $\left.100-200 \mathrm{~W}\right)$ (Omolola et al., 2014) and for pomegranate arils $\left(0.343 \times 10^{-9}-3.205 \times 10^{-9} \mathrm{~m}^{2} / \mathrm{s}, 100-300 \mathrm{~W}\right)$ (Minaei et al. 2012).

Infusion Characteristics, Total Phenolic Content (TPC) and Radical Scavenging Activity (RSA)

The total phenolic content of the fresh olive leave was found as $2385.5 \mathrm{mg}$ GAE/kg dry matter and radical scavenging activity was found as $94.5 \%$ (Table 3a). The maximum phenolic content was obtained at $167 \mathrm{~W}$ as $2282.9 \mathrm{mg} \mathrm{GAE} / \mathrm{kg}$ and minimum phenolic content as $994.5 \mathrm{mg}$ GAE $/ \mathrm{kg}$ at $347 \mathrm{~W}$. The phenolic contents of olive leaves were as $1094.5 \mathrm{mg}$ GAE/kg, $1485 \mathrm{mg}$ $\mathrm{GAE} / \mathrm{kg}$ and $1154.5 \mathrm{mg} \mathrm{GAE} / \mathrm{kg}$ that dried at 52, 90 and $290 \mathrm{~W}$ respectively. The radical scavenging activities changed from 88 to $96 \%$ and olive leaves which dried at 90 and $167 \mathrm{~W}$ had higher radical scavenging activity as well. Microwave powers had no significant effect on the radical scavenging activities $(92.5-94.5 \%) \quad(\mathrm{P}>0.05)$ except $52 \mathrm{~W}$. When comparing the results regarding the microwave power, the total phenolic contents of dried olive leaves increased up to $167 \mathrm{~W}$ but their phenolic contents decreased from 41.5 to $45.9 \%$ with the increase in microwave power of 290 and $347 \mathrm{~W}$ compared to the fresh olive leaves respectively.

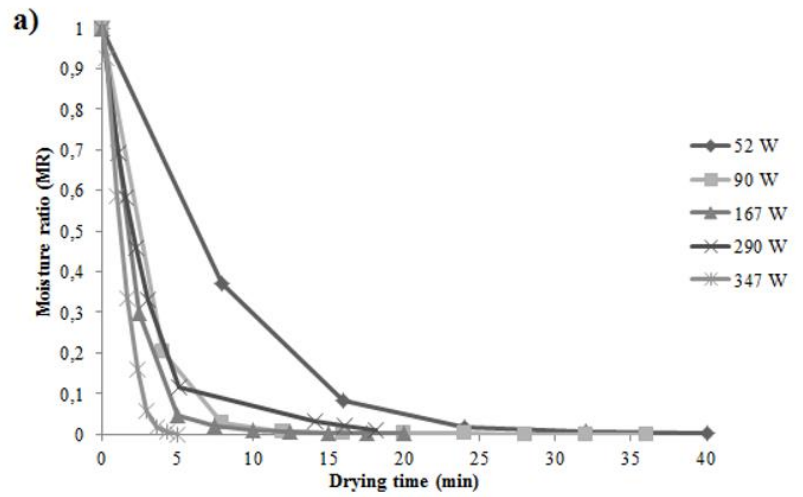

b)

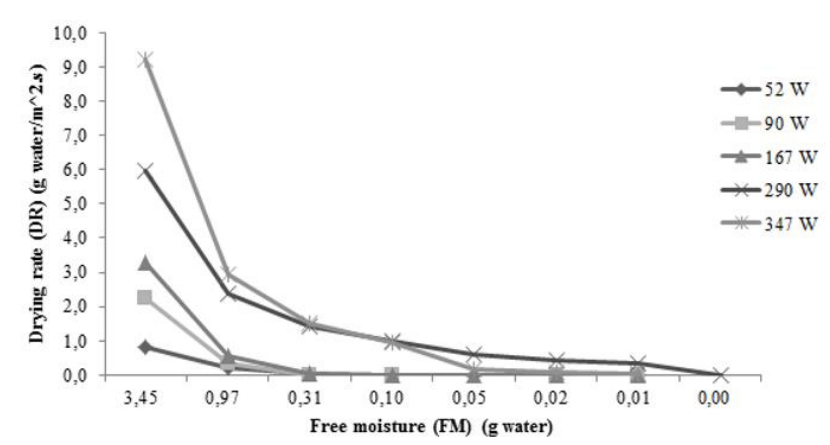

Figure 1 a) Changes in moisture ratios of olive leaves at different microwave powers b) Free moisture contents versus drying rates 
Table 2 Statistical analyses results of selected drying models

\begin{tabular}{|c|c|c|c|c|c|c|c|}
\hline \multirow{2}{*}{ Model Name } & \multicolumn{7}{|c|}{$52 \mathrm{~W}$} \\
\hline & $\mathrm{R}^{2}$ & RMSE & $\mathrm{k}$ & $\mathrm{n}$ & $\mathrm{a}$ & $\mathrm{b}$ & $\mathrm{c}$ \\
\hline Lewis & 0.996 & 0.005 & 0.348 & & & & \\
\hline Page & 0.999 & 0.005 & 0.110 & 0.663 & & & \\
\hline Mod. Page & 0.992 & 0.043 & 0.712 & -0.188 & & & \\
\hline Henderson \& Page & 0.996 & 0.022 & 0.133 & & 0.997 & & \\
\hline Logaritmic & 0.997 & 0.027 & 0.136 & & 0.990 & & -0.001 \\
\hline Two term* & 0.997 & 0.022 & 0.163 & & 0.833 & 0.157 & $0.064 *$ \\
\hline App. of Diffusion & 0.991 & 0.004 & 1.209 & & 0.009 & & \\
\hline Wang \& Singh & 0.860 & 0.135 & & & -0.051 & 0.000 & \\
\hline Simp. Fick's Diffusion & 0.996 & 0.026 & & & 0.091 & & 1.094 \\
\hline Midilli et al. & 0.978 & 0.463 & 0.159 & 0.921 & 1.000 & 0.000 & \\
\hline \multirow[t]{2}{*}{ Polynomial } & 0.990 & 0.042 & & & 0.934 & -0.078 & 0.020 \\
\hline & & & & $90 \mathrm{~W}$ & & & \\
\hline Lewis & 0.998 & 0.016 & 0.386 & & & & \\
\hline Page & 0.999 & 0.004 & 0.175 & 1.865 & & & \\
\hline Mod. Page & 0.997 & 0.050 & 0.796 & 0.485 & & & \\
\hline Henderson \& Page & 0.998 & 0.017 & 0.389 & & 1.002 & & \\
\hline Logaritmic & 0.998 & 0.017 & 0.382 & & 1.006 & & -0.004 \\
\hline Two term* & 0.998 & 0.018 & 0.387 & & 0.500 & 0.502 & $0.387 *$ \\
\hline App. of Diffusion & 0.994 & 0.004 & & & 10.780 & & 0.916 \\
\hline Wang \& Singh & 0.662 & 0.206 & & & -0.126 & 0.003 & \\
\hline Simp. Fick's Diffusion & 0.998 & 0.020 & & & 5.780 & & 0.816 \\
\hline Midilli et al. & 0.990 & 0.657 & 0.099 & 1.939 & 1.000 & 0.000 & \\
\hline \multirow[t]{2}{*}{ Polynomial } & 0.944 & 0.099 & & & 0.948 & -0.199 & 0.012 \\
\hline & & & & $167 \mathrm{~W}$ & & & \\
\hline Lewis & 0.999 & 0.011 & 0.532 & & & & \\
\hline Page & 0.999 & 0.005 & 0.393 & 1.235 & & & \\
\hline Mod. Page & 0.991 & 0.064 & 0.713 & 0.746 & & & \\
\hline Henderson \& Page & 0.994 & 0.012 & 1.004 & & 0.534 & & \\
\hline Logaritmic & 0.995 & 0.013 & 0.533 & & 1.005 & & -0.000 \\
\hline Two term* & 0.990 & 0.012 & 0.063 & & 0.161 & 0.839 & $0.156^{*}$ \\
\hline App. of Diffusion & 0.995 & 0.004 & 0.192 & & 0.499 & & \\
\hline Wang \& Singh & 0.738 & 0.181 & & & -0.051 & 0.000 & \\
\hline Simp. Fick's Diffusion & 0.993 & 0.014 & & & 0.484 & & 0.173 \\
\hline Midilli et al. & 0.943 & 0.849 & 0.165 & 2.176 & 1.000 & 0.000 & \\
\hline \multirow[t]{2}{*}{ Polynomial } & 0.965 & 0.078 & & & -0.078 & 0.020 & 0.000 \\
\hline & & & & $290 \mathrm{~W}$ & & & \\
\hline Lewis & 0.998 & 0.013 & 0.433 & & & & \\
\hline Page & 0.998 & 0.013 & 0.470 & 1.018 & & & \\
\hline Mod. Page & 0.998 & 0.014 & 0.797 & 0.544 & & & \\
\hline Henderson \& Page & 0.998 & 0.013 & 0.434 & & 1.000 & & \\
\hline Logaritmic & 0.992 & 0.014 & 0.444 & & 0.993 & & -0.010 \\
\hline Two term* & 0.992 & 0.012 & -0.971 & & 0.000 & 1.001 & $0.434 *$ \\
\hline App. of Diffusion & 0.998 & 0.015 & 0.453 & & 0.800 & & \\
\hline Wang \& Singh & 0.959 & 0.070 & & & -0.301 & 0.021 & \\
\hline Simp. Fick's Diffusion & 0.982 & 0.016 & & & 0.484 & & 0.173 \\
\hline Midilli et al. & 0.996 & 0.013 & 0.429 & 1.028 & 0.996 & 0.002 & \\
\hline \multirow[t]{2}{*}{ Polynomial } & 0.997 & 0.018 & & & -0.363 & 0.048 & -0.002 \\
\hline & & & & $347 \mathrm{~W}$ & & & \\
\hline Lewis & 0.923 & 0.103 & 0.554 & & & & \\
\hline Page & 0.999 & 0.009 & 0.582 & 1.097 & & & \\
\hline Mod. Page & 0.923 & 0.106 & 0.841 & 0.659 & & & \\
\hline Henderson \& Page & 0.946 & 0.088 & 0.629 & & 1.155 & & \\
\hline Logaritmic & 0.973 & 0.065 & 0.404 & & 1.349 & & -0.024 \\
\hline Two term* & 0.975 & 0.065 & 0.270 & & 6.01 & -4.904 & $0.222 *$ \\
\hline App. of Diffusion & 0.991 & 0.036 & 0.935 & & 2.207 & & \\
\hline Wang \& Singh & 0.974 & 0.062 & & & -0.401 & 0.039 & \\
\hline Simp. Fick's Diffusion & 0.561 & 0.273 & & & 4.267 & & 0.635 \\
\hline Midilli et al. & 0.994 & 0.008 & 0.281 & 1.953 & 0.990 & 0.001 & \\
\hline Polynomial & 0.991 & 0.039 & & & -0.340 & -0.020 & 0.009 \\
\hline
\end{tabular}

$\mathrm{k}(1 / \mathrm{min})$ and $\mathrm{n}$ are model constants; $\mathrm{a}, \mathrm{b}$ and $\mathrm{c}$ are regression coefficients, $\mathrm{k}$ and $\mathrm{c}$ belonged to $\mathrm{k}_{1}$ and $\mathrm{k}_{2}$ value respectively. 
Table 3a Total phenolics and antioxidant capacity of fresh olive leaves

\begin{tabular}{l|l}
\hline Total phenolic content (mg GAE/kg DM) & $2385.5 \pm 123.1$ \\
\hline Radical scavenging activity (\%) & $94.0 \pm 0.0$ \\
\hline
\end{tabular}

Table $3 \mathrm{~b}$ Total phenolic contents and radical scavenging activities of olive leaf teas

\begin{tabular}{|c|c|c|}
\hline \multirow{2}{*}{$\begin{array}{c}\text { Infusion Temp. } \\
\left({ }^{\circ} \mathrm{C}\right)\end{array}$} & \multicolumn{2}{|c|}{$52 \mathrm{~W}$} \\
\hline & TPC* & $\mathrm{RSA}^{* *}$ \\
\hline 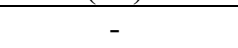 & $1094.5^{\mathrm{a}} \pm 17.3$ & $92.0^{\mathrm{a}} \pm 0.5$ \\
\hline 30 & $748.5^{c} \pm 20.5$ & $94.5^{\mathrm{b}} \pm 0.7$ \\
\hline 40 & $658.0^{\mathrm{e}} \pm 11.3$ & $94.0^{\mathrm{b}} \pm 0.0$ \\
\hline 50 & $720.0^{\mathrm{cd}} \pm 15.5$ & $89.5^{\mathrm{a}} \pm 6.4$ \\
\hline 60 & $695.5^{\mathrm{de}_{ \pm}} \pm 13.4$ & $94.0^{\mathrm{b}} \pm 0.0$ \\
\hline 70 & $930.0^{\mathrm{b}} \pm 13.4$ & $91.0^{\mathrm{a}} \pm 2.8$ \\
\hline 80 & $578.5^{f} \pm 2.12$ & $93.5^{\mathrm{a}} \pm 0.7$ \\
\hline 90 & $1038.0^{\mathrm{ba}} \pm 22.6$ & $92.0^{\mathrm{a}} \pm 1.4$ \\
\hline \multirow[t]{2}{*}{100} & $1056.0^{\mathrm{a}} \pm 43.8$ & $93.5^{\mathrm{a}} \pm 0.7$ \\
\hline & \multicolumn{2}{|c|}{$90 \mathrm{~W}$} \\
\hline- & $1485.0^{\mathrm{a}} \pm 0.0$ & $91.0^{\mathrm{a}} \pm 0.2$ \\
\hline 30 & $952.0^{\mathrm{d}} \pm 8.4$ & $93.5^{\mathrm{a}} \pm 2.1$ \\
\hline 40 & $898.5^{\mathrm{de}} \pm 14.8$ & $94.0^{\mathrm{a}} \pm 0.0$ \\
\hline 50 & $905.0^{\mathrm{d}} \pm 35.3$ & $96.0^{\mathrm{a}} \pm 2.8$ \\
\hline 60 & $787.0^{\mathrm{f}} \pm 1.4$ & $94.0^{\mathrm{a}} \pm 1.4$ \\
\hline 70 & $651.0^{\mathrm{g}} \pm 1.4$ & $92.5^{\mathrm{a}} \pm 0.7$ \\
\hline 80 & $834.5^{\mathrm{de}_{ \pm}} \pm 13.4$ & $93.5^{\mathrm{a}} \pm 0.7$ \\
\hline 90 & $1164.5^{\mathrm{c}} \pm 6.4$ & $93.5^{\mathrm{a}} \pm 0.7$ \\
\hline \multirow[t]{2}{*}{100} & $1300.5^{\mathrm{b}} \pm 71.4$ & $93.5^{\mathrm{a}} \pm 0.7$ \\
\hline & \multicolumn{2}{|c|}{$167 \mathrm{~W}$} \\
\hline- & $2282.9^{\mathrm{a}} \pm 46.3$ & $94.0^{\mathrm{a}} \pm 1.4$ \\
\hline 30 & $1188.0^{\mathrm{bcd}_{ \pm}} 74.9$ & $94.5^{\mathrm{a}} \pm 0.7$ \\
\hline 40 & $1066.0^{\mathrm{d}} \pm 86.2$ & $94.0^{\mathrm{a}} \pm 1.4$ \\
\hline 50 & $1082.5^{\mathrm{cd}_{ \pm}}+13.4$ & $94.0^{\mathrm{a}} \pm 0.0$ \\
\hline 60 & $1029.0^{\mathrm{d}} \pm 33.9$ & $93.5^{\mathrm{a}} \pm 0.7$ \\
\hline 70 & $711.5^{\mathrm{e}} \pm 173.2$ & $93.0^{\mathrm{a}} \pm 0.0$ \\
\hline 80 & $1208.0^{\mathrm{bcd}_{ \pm}} 48.1$ & $93.0^{\mathrm{a}} \pm 1.4$ \\
\hline 90 & $1697.5^{\mathrm{bc}} \pm 6.4$ & $90.0^{\mathrm{a}} \pm 4.2$ \\
\hline \multirow[t]{2}{*}{100} & $2072.7^{b} \pm 82.0$ & $92.5^{\mathrm{a}} \pm 0.7$ \\
\hline & \multicolumn{2}{|c|}{$290 \mathrm{~W}$} \\
\hline- & $1154.5^{\mathrm{a}} \pm 23.7$ & $90.5^{\mathrm{a}} \pm 0.2$ \\
\hline 30 & $760.0^{\mathrm{d}} \pm 9.1$ & $92.5^{\mathrm{a}} \pm 0.7$ \\
\hline 40 & $877.0^{c} \pm 15.5$ & $92.5^{a} \pm 0.7$ \\
\hline 50 & $757.5^{\mathrm{d}} \pm 7.7$ & $92.0^{\mathrm{a}} \pm 0.0$ \\
\hline 60 & $893.0^{c} \pm 42.4$ & $92.0^{\mathrm{a}} \pm 1.4$ \\
\hline 70 & $968.0^{b c} \pm 11.3$ & $92.0^{\mathrm{a}} \pm 1.4$ \\
\hline 80 & $900.5^{\mathrm{c}} \pm 81.3$ & $91.0^{\mathrm{a}} \pm 0.0$ \\
\hline 90 & $1048.5^{\mathrm{ab}} \pm 44.5$ & $90.0^{\mathrm{a}} \pm 0.0$ \\
\hline \multirow[t]{2}{*}{100} & $1087.5^{\mathrm{a}} \pm 36.0$ & $90.5^{\mathrm{a}} \pm 0.7$ \\
\hline & \multicolumn{2}{|c|}{$347 \mathrm{~W}$} \\
\hline- & $994.5^{\mathrm{a}} \pm 3.2$ & $91.5^{\mathrm{a}} \pm 2.2$ \\
\hline 30 & $596.0^{c} \pm 4.2$ & $89.5^{\mathrm{a}} \pm 0.7$ \\
\hline 40 & $611.5^{c} \pm 6.3$ & $88.0^{\mathrm{a}} \pm 4.2$ \\
\hline 50 & $668.5^{\mathrm{c}} \pm 0.7$ & $93.0^{\mathrm{a}} \pm 0.0$ \\
\hline 60 & $874.5^{\mathrm{b}} \pm 188.7$ & $92.0^{\mathrm{a}} \pm 2.8$ \\
\hline 70 & $661.5^{\mathrm{b}} \pm 44.5$ & $93.0^{\mathrm{a}} \pm 0.0$ \\
\hline 80 & $847.5^{b} \pm 10.6$ & $93.0^{\mathrm{a}} \pm 0.0$ \\
\hline 90 & $890.0^{\mathrm{b}} \pm 55.1$ & $92.0^{\mathrm{a}} \pm 16.3$ \\
\hline 100 & $928.5^{\mathrm{b}} \pm 10.6$ & $92.0^{\mathrm{a}} \pm 0.7$ \\
\hline
\end{tabular}

indicate significant difference at $\mathrm{P}<0.05$. Each value are the mean of two
Polyphenols were secluded within vacuoles in healthy intact plant tissue to preserve the compounds from oxidation, and only or physical breakdown of the plant tissue structures are phenolics exposed to oxygen (PuenteDiaz et al., 2013). The cell wall destruction may activate the release the enzymes that would destroy the phenolics in olive leaves. So, drying process with higher microwave power would damage the oxidative and hydrolytic enzymes and prohibit the loss of polyphenols. The result of microwave heating of olive leaves revealed that microwave drying process could enhance the phenolic content up to $360 \mathrm{~W}$. Similar trend was observed in Ghanem et al. (2012)' study. They dried lemon and thompson peels in microwave at different power levels like $100,180,300,450$ and $600 \mathrm{~W}$ and stated that between 100 and $300 \mathrm{~W}$, the phenolic contents of thompson peels decreased, however after $300 \mathrm{~W}$, the amounts of phenolics increased. In lemon peels, up to 450 $\mathrm{W}$, the phenolics raised continuously. Nevertheless, at $600 \mathrm{~W}$, the phenolics degraded. High or low levels of phenolic substances could be changed depending on plant material (Hamrouni-Sellami et al., 2013).

Many studies confirmed a linear relationship between total phenolic contents and antioxidant activities (Olivieira et al., 2012) and increasing total phenolic content of material such as radix angelicae sinensis extracts (RAS) had a higher DPPH with in terms of $\mathrm{mg}$ PYR/g and caffeic, ferrulic acid compounds exerted more antioxidant capacity than other phenolic compounds in the RAS extracts (Li et al., 2009). Değirmencioğlu et al. (2016) also reported that microwave dried tarhana samples depicted higher DPPH and ABTS values compared to other drying methods. Owing to pharmacological effects on health, the dried olive leaves are converted to the different products. One of the products is olive leaf tea which is obtained from dried olive leaves which milled and sieved at a size of 2-3 mm by infusing with water between 8 and 10 minutes (Anonymous, 1983). The total phenolic contents of infused leaf tea were changed from $578.5 \mathrm{mg} \mathrm{GAE} / \mathrm{kg}$ to $2072.7 \mathrm{mg} \mathrm{GAE} / \mathrm{kg}$ and increasing infusion temperature increased the total phenolic content of leaf tea as shown in Table 3b.

There are many extraction processes for recovering of polyphenols from olive leaves, especially oleuropein such as methanol, ethanol, acetonitrile, hexane, acidified water, mixture of these solvents with water and also an extraction in $80 \%$ methanol is the most effective method for polyphenols from olive leaves (Yateem et al., 2014; Mkhaour et al., 2015; Şahin and Bilgin, 2012). The boiling of dried olive leaves is also a very efficient method for extracting oleuropein and verbascoside that gave 96 and 94\% recoveries of these compounds respectively (Malik and Bradford, 2008) and also the mixture of ethanol-water is highly recommended as cosolvents for their non-toxicological, environmental and low cost considerations for recovering of polyphenols (Şahin and Bilgin, 2012). These studies confirm that water is a good solvent for extracting polyphenols from olive leaves and also increasing extraction temperature $\left(90-100^{\circ} \mathrm{C}\right)$ results an increase in total phenol levels from olive leaves so the results of infusion temperatures especially $100^{\circ} \mathrm{C}$ confirmed high recovery of polyphenols 
from olive leaves (Table 3 ). The olive leaf teas extracted at $100^{\circ} \mathrm{C}$ had relatively higher phenolic content, so consuming olive leaf tea by infusing with hot water $\left(100^{\circ} \mathrm{C}\right)$ could be a good method to recover polyphenols. It can be helpful for protecting from cancer, immune and cardiovascular system diseases.

\section{Conclusion}

In this study, the leaves of olive trees (Gemlik cv.) grown in Osmaniye were dried at different microwave powers from 52 to $347 \mathrm{~W}$ by modeling drying behavior using thin layer equations.Page model $\left(\mathrm{R}^{2}: 0.998-0.999\right)$ gave the best fitting results and an increment in microwave power caused also an increase in rate constant " $k$ " because of rapid moisture removal. The effective moisture diffusivity of olive leaves changed from $2.650 \times 10^{-10}$ to $1.320 \times 10^{-9}\left(\mathrm{~m}^{2} / \mathrm{s}\right)$ and the maximum value was observed in maximum power.

When regarding the phenolic contents of dried olive leaves, leaves dried at $167 \mathrm{~W}$ and $347 \mathrm{~W}$ had the highest and lowest phenolicsrespectively. Infusion temperature of leaf tea affected recovering polyphenols and maximum extraction obtained at $100^{\circ} \mathrm{C}$ from 8 to 10 minutes of infusion. The extraction levels of olive leaf tea showed that water was a good solvent for extracting polyphenols. With these findings, it is believed that olive leaf tea has a potential of being a cheaper and healthy alternative of black tea which is consumed widely especially in Turkey, because of growing abundantly and having high polyphenol content and antioxidant activity. Furthermore, microwave drying could be applicable in production of tea due to presenting higher drying rates and expressed mathematical model results will give opinion to manufacturers, scientists and engineers who are interested in designing of new equipments.

\section{References}

Anoynmous. 1983. Black tea. The institue of Turkish standardization. TS 3907, ICS 67.140.10,67,240.

Boudhrioua N, Bahloul N, Ben Slimen I, Kechaou N. 2009. Comparison on the total phenol contents and the color of fresh and infrared dried olive leaves. Ind Crops Prod., 29(23): 412-419.

Chua KJ, Mujumdar AS, Hawlader MNA, Chou SK, Ho JC. 2001. Batch drying of banana pieces-effect of stepwise change in drying air temperature on drying kinetics and product colour. Food Res Int., 34: 721-731.

Değirmencioğlu N, Gürbüz O, Herken EN, Yıldız AY. 2016. The impact of drying techniques on phenolic compound, total phenolic content and antioxidant capacity of oat flour tarhana. Food Chem., 194: 587-594.

El SN, Karakaya S, 2009. Olive tree (Olea europaea) leaves: potential beneficial effects on human health. Nutr Rev., 67: 632-638.

Erbay Z, Icier F. 2009. Optimization of hot air drying of olive leaves using response surface methodology. J Food Eng., 91(4): 533-541.

Erbay Z, Icier F. 2010. Thin-layer drying behaviors of olive leaves (Olea europaea L.). J Food Process Eng., 33: 287-308.

Fernandes de Oliveira AM, Sousa Pinheiro L, Souto Pereira CK, Neves Matias W, Albuquerque Gomes R, Souza Chaves O, Simões de Assis T. 2012. Total phenolic content and antioxidant activity of some Malvaceae family species. Antioxid., 1(1): 33-43.
Ferreira IC, Barros L, Soares ME, Bastos ML, Pereira JA. 2007. Antioxidant activity and phenolic contents of Olea europaea L. leaves sprayed with different copper formulations. Food Chem., 103(1): 188-195.

Figiel A. 2010. Drying kinetics and quality of beetroots dehydrated by combination of convective and vacuummicrowave methods. J Food Eng., 98(4): 461-470.

Gamlı ÖF. 2011. Effective moisture diffusivity and drying characteristics of tomato slices during convectional drying. G1da, 36(4): 201-208.

Gamli ÖF, Süfer Ö, Eker T. 2016. Convective drying kinetics and phenolic contents of olive leaves. J Food Phys., 28: 1420.

Gaware TJ, Sutar N, Thorat BN. 2010. Drying of tomato using different methods: comparison of dehydration and rehydration kinetics. Dry Technol., 28: 651-658.

Ghanem N, Mihoubi D, Kechaou N, Mihoubi NB. 2012. Microwave dehydration of three citrus peel cultivars: Effect on water and oil retention capacities, color, shrinkage and total phenols content. Ind Crops Prod., 40(1): 167-177.

Goncalves LT, Pereira NR, Almeida SB, Freitas SD, Waldman WR. 2017. Microwave-hot air drying applied to selected cassava cultivars: drying kinetics and sensory acceptance. Int J Food Sci Technol., 52(2): 389-397.

Hamrouni-Sellami I, Rahali FZ, Rebey IB, Bourgou S, Limam F, Marzouk B. 2013. Total phenolics, flavonoids, and antioxidant activity of sage (Salvia officinalis L.) plants as affected by different drying methods. Food Bioprocess Technol., 6: 806-817.

Huang D, Ou B, Prior RL. 2005. The chemistry behind antioxidant capacity assays. J Agric Food Chem., 53(6): 1841-1856.

Kumar PS, Kanwat M, Choudhary VK. 2013. Mathematical modeling and thin-layer drying kinetics of bamboo slices on convective tray drying at varying temperature. J Food Process Preserv., 37(5): 914-923.

Lewicki PP. 2006. Design of hot air drying for better foods. Trends Food Sci Technol., 17: 153-163.

Li X, Wu X, Huang L. 2009. Correlation between antioxidant activities and phenolic contents of radix Angelicae sinensis (Danggui). Molecules, 14(12): 5349-5361.

Malik NS, Bradford JM. 2008. Recovery and stability of oleuropein and other phenolic compounds during extraction and processing of olive (Olea europaea L.) leaves. J Food Agric Environ., 6(2): 8.

Maskan M. 2001. Kinetics of colour change of kiwifruits during hot air and microwave drying. J Food Eng., 48(2): 169-175.

Mkaouar H, Zalila B, Hugues J, Jmaiel M. 2015. From AADL Model to LNT Specification. In: de la Puente J., Vardanega T. (eds) Reliable Software Technologies - Ada-Europe 2015. Ada-Europe 2015. Lecture Notes in Computer Science, vol 9111. Springer, Cham.

Midilli A, Kucuk H, Yapar Z. 2002. A new model for singlelayer drying. Dry Technol., 20(7): 1503-1513.

Minaei S, Motevali A, Ahmadi E, Azizi MH. 2012. Mathematical models of drying pomegranate arils in vacuum and microwave dryers. J Agr Sci Tech., 14: 311325.

Nourhène B, Mohammed K, Nabil K. 2008. Experimental and mathematical investigations of convective solar drying of four varieties of olive leaves. Food Bioprod Process., 86: $176-184$.

Nurs Lokman Hekim Company. www.nurs.com.tr, Adana, Turkey.

Omar SH. 2010. Oleuropein in olive and its pharmacological effects. Sci Pharm., 78(2): 133-154.

Omolola AO, Jideani AIO, Kapila PF. 2014. Modeling microwave drying kinetics and moisture diffusivity of Mabonde banana variety. Int J Agr Biol Eng., 7(6): 107-113. 
Paiva-Martins F, Pinto M. 2008. Isolation and characterization of a new hydroxytyrosol derivative from olive (Olea europaea) leaves. J Agric Food Chem., 56(14): 5582-5588.

Puente-Díaz L, Ah-Hen K, Vega-Gálvez A, Lemus-Mondaca R, Di Scala K. 2013. Combined infrared-convective drying of murta (Ugni molinae Turcz) berries: kinetic modeling and quality assessment. Dry Technol., 31: 329-38.

Sharma GP, Prasad S. 2004. Effective moisture diffusivity of garlic cloves undergoing microwave-convective drying. J Food Eng., 65(4): 609-617.

Sharma SR, Arora S, Chand T. 2011. Air drying kinetics of pomegranate seeds. Int J Food Eng., 7(2).

Souilem S, Fki I, Kobayashi I, Khalid N, Neves MA, Isoda H, Sayadi S, Nakajima M, 2017. Emerging technologies for recovery

value-added components from olive leaves and their applications in food/feed industries. Food Bioprocess Technol., 10: 229-248.

Şahin S, Bilgin M. 2012. Study on oleuropein extraction from olive tree (Olea europaea) leaves by means of SFE: Comparison of Water and Ethanol as Co-Solvent. Sep Sci Technol., 47: 2391-2398.
Toujani M, Hassini L, Azzouz S, Belghith A. 2013. Experimental study and mathematical modeling of silverside fish convective drying. J Food Process Preserv., 37: 930938.

T.S.M.S. (2015). Turkish State Meteorological Service.

Tuck KL, Hayball PJ. 2002. Major phenolic compounds in olive oil: metabolism and health effects. J Nutr Biochem., 13(11): 636-644.

Visioli F, Bellomo G, Montedoro G, Galli C. 1995. Low density lipoprotein oxidation is inhibited in vitro by olive oil constituents. Atherosclerosis, 117(1): 25-32.

Wiktor A, Iwaniuk M, Śledź M, Nowacka M, Chudoba T, Witrowa-Rajchert D. 2013. Drying kinetics of apple tissue treated by pulsed electric field. Dry Technol., 31(1): 112119.

Yateem H, Afaneh I, Al-Rimawi F. 2014. Optimum conditions for oleuropein extraction from olive leaves. Int J Appl Sci Technol., 4(5): 153-457.

Zhang M, Jiang H, Lim RX. 2010. Recent developments in microwave-assisted drying of vegetables, fruits, and aquatic product-Drying kinetics and quality considerations. Dry Technol., 28(11): 1307-1316. 